tissue possesses of resisting the growth of other living tissue within it, which is, in fact, one of the chief signs of its vitality, it is obvious that the more this vital resisting power is a aed up against ordinary germs of decomposition, the less will be left to withstand the development of the more special micro-organisms which are concerned in the production of disease. It seems fair, then, to believe that if we so arrange our lives that we shall commonly eat partly decomposing food, drink bacterial water, and breathe germ-laden air, even although neither the food, nor the water, nor the air contain anything which is capable of producing disease, we shall so exhaust and use up, if I may so sav, the vital resistance of our tissues that, although we may still appear in good health, but little power may be left to us of resisting the development and multiplication within our bodies of any disease germs which may come across our path. These views as to the importance of the preceding condition in permitting the development of germs into disease are strengthened by the recent discovery of the bacterial origin of tubercle; for here we have an instance in which the contagion habitually passes over the strong to attack those who are fitted for it either by constitution or by preceding disease, or by reducing surroundings, and even when it has picked out a feeble member of the flock and attacked such an organ as the lung, is usually impotent against tho*e portions whose functional activity is greatest, and is prone to affect those in which renewal of air and removal of exfoliated epithelium are least perfectly performed, such as party which have heen inflamed or tied down by previous thickening of the pleura, and especially the comparatively unused apices of the lungs. When we see the chest, of a phthisical patient covered with patches of cloasma, the thickened and unremoved epithelium infiltrated by the spores and mycelium of the microsporon furfur, we carry the mind's eye inwards and think of the apices of the lungs and the similar processes going on within them, their air cells, little moved by the feeble respiratory efforts of the patient, gradually plugging up with exfoliated epithelium matted together by the growth of tubrrcular bacilli, which, although carried

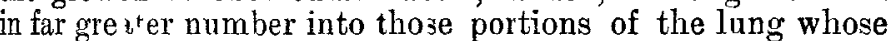
functional activity is greater, have only been able to take root in the half-dead epithelinm of the stagnant apicial air cells. All these thoughts put one more in sympathy with those who aim at warding off infertious disease by general improved stuitation, ratber than with those who try to keep it at bay by isolation and quarantine. One cannot help seeing that if these latter do not combine with their efforts to stamp out disease by isolation of the germ-producing patient, such measures as shall in the meantime diminish the receptivity of the people, their fitness for breeding within them these germs of disease, the only result will be that some time or other the contagion will break through the quarantine, and run riot in a universally susceptible population. Let us, therefore, while earnestly studying the micro-organisms, which are the essential causes of the whole class of in fectinus diseases, also investigate and search rut the conditions of bo:ly under which they are capable of developing within the animal frame, trusting that we may so be enabled to find some means of rendering ourselves unfit breeding grounds, at any rate for those which are least virulent, and hoping that the same measures which do this may so $f_{d r}$ dirmin!sh our receptivity for the others as to make their atracks less frequent and less fatal.

Halifax.

\section{ACUTE CONJUNCTIVITIS CAUSED BY THE ELECTRIC LIGHT.}

\section{By W. C. ROCKLIFFE, M.A., M.D.}

So far as I am acquainted with our English literature and periodicals, I am not aware that the effect of the electric light on the eve as producing acute conjunctivitis has been mentioned. The following case being the first I have met with, may therefore be of interest to the readers of THE LAYCET.

A. B-_, aged twenty-eight, was recently engaged in placing Siemens' electric light in the old part of the town, and, together with his fellow.workman, adjusting the carbon points of a lamp with 3000 candle power without coloured glasses, which he informs me are always supposed to be worn during this portion of his business. As an almost daily occurrence the brilliancy of the spark causes more or less paralysis of the retina, or, to quote his own words, "he rarely is able to perceive the people walking on the footpath' when descending the ladder from adjusting." Although this effect soon passes off, on this particular occasion, as he regained his power of vision (in about fifteen minutes), it was followed by rapidly increasing lacrymation, photophobia, pain and swelling of the lids, the whole symptoms being developed in thirty minutes. Having suffered from many slight attacks of a similar nature, he applied cold water, which previously had relieved him; but the pain and swell. ing increasing, I saw him the following day, apparently having suffered intense agony during the night. The lids of both eyes were very hot, red, swollen, and brawny, and level with the superciliary ridge, the swelling extending some little distance upwards over the forehead. The pain was most acute in and around the eye. On raising the lids (which was a very difficult operation, the photophobia being so very intense) a considerable amount of lacrymal fluid gusbed out. The conjunctival vessels were exceedingly large, and the eyeball a brilliant scarlet ; cornea clear. All these symptoms yielded to a brisk purge and lead lotion in forty-eight hours. His fellow-workman was similarly affected, but to a less extent.

As a considerable heat is thrown out from the lamp, it would be interesting to know whether these symptoms were caused by the brilliancy or radiant heat.

Hull.

\section{NEW SPLINT-RFST FOR SYME'S AMPUTA- TION.}

By HENRY A. LEDIARD, F.R.C.S. ENG., \&c., SURGEON TO THE CUMBERLAND INFIRMARY.

THE accompanying woodeut represents a splint-rest which has been made for me by the infirmary joiner under the direction of $\mathrm{Mr}$. A. Proffitt, our house-surgeon at present. I have remarked that the ordinary straight back splint, although most valuable in many amputations, fails to give support, if necessary, to the heel-flap in Syme's amputation. I allude to cases where the stitches are subjected to strain, and to cases where union of the flaps is delayed from some cause, and where adhesive plaster is employed after the stitches have been taken out. Again, in the usual dorsal position of the body after Syme's amputation, the cut end of the tibia tends to project somewhat from the drooping of the heel-flap, which is sometimes more bulky and heary than at others, according to the nutrition of the patient and amount of tissue

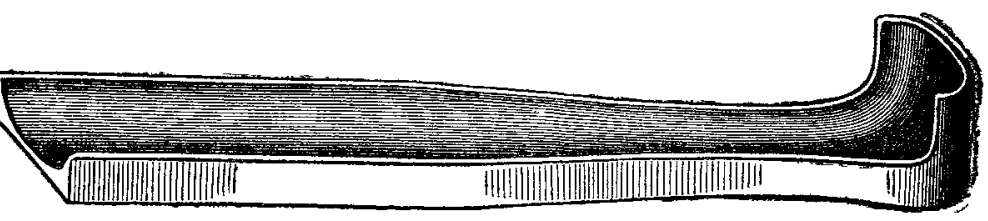

available. I have lately tried the effect of a wooden splint so shaped as to fit the end of the stump and support its side and end. In order to promote drainage and to relieve tension, my old master, the late lamented Professor Spence, was in the habit of placing his Syme's amputations upon their sides and bending the knee. The discharge would thus drain through the outer angle of the flap, near where the tip of the external malleolus hail been. This is an excellent method in some instances, if the lateral posture is tolerated, but the stump has occasionally a tendency to slew round, and to require readjusting with plaster. I consider, then, that the splint-rest figured will afford another step towards that rest and freedom from pain so essential in the treatment of wounds, which Hinton and Callender both taught and practised.

There are some Syme's amputations which do not require a thought from the moment of the completion of the operation, even strapping after removal of the stitches being wholly unnecessary; but it is not so in all, and whether the latter are treated with Listerism or the open method, I think that in a few cases my splint will be found serviceable. It will be observed that the splint is hollowed for the calf, as well as shaped for the stump end.

Carlisle. 